\title{
Study on Female Industrial Structure and Gender Segregation of China in the New Century
}

\author{
Hui Yang* (Corresponding author) \\ Laws, Regulations, and Policies Research Section of \\ Women's Studies Institute of China, All-China Women's Federation \\ No. 50, Dengshikou Dajie, Dongcheng District, Beijing, China \\ Tel: 86-10-6510-3469Ｅ-mail: yanghui10@126.com
}

Received: October 16, 2014 Accepted: November 4, 2014 Published: January 14, 2015

doi:10.5296/ijssr.v3i1.6908

URL: http://dx.doi.org/10.5296/ijssr.v3i1.6908

\begin{abstract}
In the first decade of the $21^{\text {st }}$ century, China has not only achieved stable and rapid economic development, but also made new progresses in industrial restructuring. The modern service industry and emerging strategic industries have provided more employment opportunities for laborers including women.
\end{abstract}

Purpose- The purpose of this article is to analyze the gender segregation status and trend in the industry of China in the new century.

Data/Methodology - The research includes items of female industriall structure, gender segregation. Data come from 29696 valid respondents by the Third Survey of Chinese Women's Social Status questionnaire survey which was jointly organized by the All-China Women's Federation and the National Bureau of Statistics starting on December 1, 2010. The Methodologies applied in this paper are descriptive statistics and binary logistic regression.

Findings- China's employment women are mainly concentrated in the lower income levels and lower social security industries in 2010. Among the monopoly industries, 80 percent of them are male which indicates that women can share only a small amount of social development outcomes. Compared with the status of 10 years ago, China's employment industry structure has changed as follows. Firstly, the female industry structure presents polarization trend. The proportion of women in the 10 monopolies declined, and the

\footnotetext{
* Hui YANG, Associate Research Fellow of Women's Studies Institute of China, All-China Women's Federation. Hui Yang's
} research interests are Feminist economic development and social security. 
proportion of women in modern service industry improved. Secondly, the proportion of men in some traditional industries improved. Last but not least, age and education have significantly statistical effects on the opportunities of modern service industries' employment.

Originality/Value- This research studied the gender segregation status and trend in the industry of China in the new century. The results of this research provide empirical evidence that the ten monopolies gender segregation status of China is more serious than 10 years ago. Age and education of female have significantly statistical effects on the opportunities of modern service industries' employment. That is to say, well-educated young women have more opportunities to work in modern service industries.

Keywords: employment structure, gender segregation, status and trends

\section{Introduction}

In the first decade of the $21^{\text {st }}$ century, China has not only achieved stable and rapid economic development, but also made new progresses in industrial restructuring; the modern service industry and emerging strategic industries have provided more employment opportunities for laborers including women. Data from the Third Survey of Chinese Women's Social Status shows that the employment rate of Chinese women aged 18-64 in 2010 was 71.4 percent. Then, which industries are these employed women mainly distributed in? Compared with the situations of 10 years ago, what changes have taken place in the female industrial structure? How are the conditions of gender segregation in the industrial structure? These questions are of great significance for a comprehensive understanding of the quality of females' employment as well as their roles in the national economy, which can provide some supporting data for promoting the coordinated development of the industrial gender structure.

\section{Literature review}

Due to the limitations of research perspectives, survey data and other factors, Chinese scholars have barely made special studies on the female industrial structure. The author searched in cnki.net with the title, the subject and keywords about gender segregation in the industrial structure, and only found 9 journal articles or dissertations. Foreign literature and books concerning the female industrial structure are relatively more than that of China.

Occupational segregation is mostly discussed in terms of gender segregation, in works such as those of Blau and Hendricks (1979) and Anker (1997). Overseas studies found that technological advances have decreased the employment proportion of agricultural and industrial sectors, and increased job opportunities in transportation, telecommunications, finance, insurance and other service industries (Blazejczak, 1991). According to Rendall (2010), the changes in the employment structure of the United States enabled many women to work in the service industry. Irene et al. (2010) discovered that most women in Switzerland were limited in just a few industries, such as, education, health care, catering and accommodations. While creating more employment opportunities for women, technological advances and changes in the structure of employment have also restrained women from developing in different industries. Falk (2002) discussed gender segregation in East and West Germany, Kohn and Antoncyk (2011) broadly discussed the labor market effects of the 
German re-unification in 1990. Stephan (2013) found that both age and gender-specific segregation do exist in Germany. It is not only the difference between men and women, but also the difference between young and old. There is evidence for a long-term decline in occupational segregation for both genders in Western Germany.

In the textile, commercial and service industries in China, more than half of the employees are women (Zhang, 2010). Seen from the perspective of industry composition, the wholesales and retails, the food and beverage industries are the largest in the number of urban and township female employees (Jiang, 2006). Recent years have seen that gender segregation is intensified to certain degrees (Luo, 2008). However, in order to grasp the female industrial structure and gender segregation in the new century, it is necessary to use the latest large-scale survey data to conduct studies and analysis.

\section{Data and Methodology}

In this paper, based on the raw data of the Third Survey of Chinese Women's Social Status, supplemented by the Sixth National Population Census of the People's Republic of China, the industrial gender structure and gender segregation in the new century of China are studied from three dimensions: female industrial structure, gender segregation in industries with higher degrees of monopoly, and gender parity in the modern service industry.

Descriptive statistics and binary logistic regression model are applied in this study. The rationale for this model is to establish a regression model based on the Third Survey of Chinese Women's Social Status, which was jointly organized by the All-China Women's Federation and the National Bureau of Statistics. The probabilistic relation between several independent variables and one particular value of a dependent variable is determined, thus simulating the varying pattern of the event of concern. There are only two values to be assigned to the dependent variable in binary logistic model, namely, 1 or 0 , representing two probabilities of whether working in modern service industry. Suppose $\mathrm{x}_{1}, \mathrm{x}_{2}, \ldots, \mathrm{x}_{\mathrm{i}}$ represent the i factors affecting Y. In the process of statistical analysis of data, denote the probability of working in modern service industry as $\mathrm{P}(\mathrm{Y}=1)$, and the probability of not-working in modern service industry as $1-\mathrm{P}(\mathrm{Y}=0)$. The ratio of $\frac{\mathrm{p}}{1-\mathrm{p}}$ is the odds, or preponderance. The odds bigger than 1 means the probability of working in modern service industry surpasses the probability of not-working in modern service industry, i.e. working in modern service industry is in preponderance. Denote the logarithm of the odds as $\ln \frac{p}{1-p}$, i.e. Logistic conversion of $\mathrm{P}$ recorded as logit $(\mathrm{P})$ :

$\operatorname{Logit}(\mathrm{P})=\mathrm{Y}=\ln \frac{\mathrm{p}}{1-\mathrm{p}}=\alpha+\beta_{1} \mathrm{x}_{1}+\beta_{2} \mathrm{x}_{2}+\ldots+\beta_{i} \mathrm{x}_{i}$

$\mathrm{P}=\frac{\exp \left(\beta_{1} \mathrm{x}_{1}+\beta_{2} \mathrm{x}_{2}+\cdots+\beta_{i} \mathrm{x}_{i}\right)}{1+\exp \left(\beta_{1} \mathrm{x}_{1}+\beta_{2} \mathrm{x}_{2}+\cdots+\beta_{i} \mathrm{x}_{i}\right)}$

Where $\alpha$ is a constant term, representing the natural logarithm of odds when all the values of 
the independent variables are $0 . \beta_{i}$ is the partial regression coefficient of this equation, representing the effect of variable $\mathrm{x}_{i}$ on $\mathrm{Y}$. When its value is positive and statistically significant, it means that the value of $\mathrm{Y}$ increases with the increase of the explaining variable $\mathrm{x}_{i}$. On the contrary, when the regression coefficient is negative, it means that $\mathrm{Y}$ decreases with the increase of $\mathrm{x}_{i}$.

\section{Selecting dependent valuable}

The dependent valuable involved in this study is whether working in modern service industry, a qualitative dichotomous variable. If the result is "working in modern service industry", the dependent variable $\mathrm{Y}=1$; if not, the dependent variable $\mathrm{Y}=0$.

\section{Selecting independent variables}

6 independent variables are dichotomous variables, such as sex, whether working in urban area, the way of getting work whether is by organization, whether experienced career break, whether is Communist Party membership or not, whether agree to the ability of women is poorer than that of men. The other 4 independent variables are categorical variables, such as age group, education, area, and place of birth. $\mathrm{x}_{1}-\mathrm{x}_{10}$ as independent variables (see Table 1).

Table 1. Values and types of independent variables

\begin{tabular}{|c|c|c|c|}
\hline Independent variables & Code & Value & Type \\
\hline Sex & $\mathrm{x}_{1}$ & Male(0), Female(1) & Dichotomous \\
\hline $\begin{array}{l}\text { Whether working in urban } \\
\text { area }\end{array}$ & $\mathrm{x}_{2}$ & No(0),Yes(1) & Dichotomous \\
\hline $\begin{array}{l}\text { The way of getting work } \\
\text { whether is by organization }\end{array}$ & $\mathrm{x}_{3}$ & No(0),Yes(1) & Dichotomous \\
\hline $\begin{array}{l}\text { Whether experienced } \\
\text { career break }\end{array}$ & $\mathrm{x}_{4}$ & No(0), Yes(1) & Dichotomous \\
\hline $\begin{array}{l}\text { Whether is Communist } \\
\text { Party membership or not }\end{array}$ & $\mathrm{x}_{5}$ & No(0), Yes(1) & Dichotomous \\
\hline $\begin{array}{l}\text { Whether agree to the } \\
\text { ability of women is poorer } \\
\text { than that of men }\end{array}$ & $\mathrm{x}_{6}$ & No(0),Yes(1) & Dichotomous \\
\hline Age group & $\mathrm{x}_{7}$ & $\begin{array}{l}\text { 60-64 years old ( } 0 \text { ), } 18-29 \text { years old ( } 1), 30-39 \text { years } \\
\text { old ( } 2 \text { ), } 40-49 \text { years old (3), } 50-59 \text { years old ( } 4 \text { ) }\end{array}$ & $\begin{array}{l}\text { Categorical } \\
\text { variables }\end{array}$ \\
\hline Education & $\mathrm{x}_{8}$ & $\begin{array}{l}\text { Secondary and below (0), High school (1), College } \\
\text { and above (2) }\end{array}$ & $\begin{array}{l}\text { Categorical } \\
\text { variables }\end{array}$ \\
\hline Area & $\mathrm{x}_{9}$ & $\begin{array}{l}\text { west area (0), Beijing, Tianjin, Shanghai (1), East } \\
\text { area (2), Middle area (3) }\end{array}$ & $\begin{array}{l}\text { Categorical } \\
\text { variables }\end{array}$ \\
\hline Place of birth & $\mathrm{x}_{10}$ & $\begin{array}{l}\text { Rural area (0), Town (1),County including } \\
\text { county-level cities (2), City prefecture-level cities } \\
\text { and above (3) }\end{array}$ & $\begin{array}{l}\text { Categorical } \\
\text { variables }\end{array}$ \\
\hline
\end{tabular}




\section{Findings}

\subsection{Female Industrial Structure of China in the New Century}

Employed females are mostly concentrated in the sectors with lower levels of income and social security. The proportions of females in 7 out of 20 industrial categories in 2010 approached or exceeded 50 percent. Such a finding coincides with the research result of $\mathrm{Xu}$ Yiran (2012). Farming, forestry, animal husbandry, fishery and water conservancy, as well as accommodation and catering, wholesales and retails which accommodate the most employed female populations are the typical marginalized sectors with lower level of average labor compensations (see Table 2). Meanwhile, the proportions of females in the rest 7 industries are lower than 40 percent, especially in construction, mining, transportation, storage and postal industries, where the proportions of women are less than 16 percent, wherein the degree of gender segregation in the construction industry coincides with the research of $\mathrm{Xu}$ Dingquan and Yang Zongwei (2012). Among the seven industrial categories where women are put in the absolute subordinate position, five categories (such as the information transmission, computer services and software category; the scientific and technical services and geological prospecting category; the water conservancy, environment and public facilities management category; the water, electricity and gas production and supply category; the transportation, storage and postal service category) are high-income monopoly industries or industries with high social power.

Table 2. Sex structure by industry in the year of 2000 and 2010 (\%)

\begin{tabular}{|c|c|c|c|c|}
\hline & \multicolumn{2}{|c|}{$\begin{array}{l}\text { Women accounting for the } \\
\text { proportion of staff in the industry }\end{array}$} & \multicolumn{2}{|c|}{$\begin{array}{l}\text { Industry structure of } \\
\text { female }\end{array}$} \\
\hline & Year of 2000 & Year of 2010 & $\begin{array}{c}\text { Year of } \\
2000\end{array}$ & $\begin{array}{c}\text { Year of } \\
2010\end{array}$ \\
\hline Agriculture, Forestry, Animal Husbandry and Fishery & 50.3 & 49.1 & 70.7 & 45.7 \\
\hline Mining & 20.3 & 15.8 & 0.3 & 0.4 \\
\hline Manufacturing & 47.7 & 42.7 & 10.0 & 12.5 \\
\hline Production and Distribution of Electricity, Gas and Water & 26.3 & 27.0 & 0.3 & 0.7 \\
\hline Construction & 12.7 & 10.4 & 0.5 & 1.0 \\
\hline Transport, Storage and Post & 19.8 & 15.5 & 1.2 & 1.6 \\
\hline Information Transmission, Computer Service and Software & 64.7 & 33.5 & 0.1 & 0.6 \\
\hline Wholesale and Retail Trades & 53.2 & 53.8 & 5.0 & 11.2 \\
\hline Hotels and Catering Services & 62.9 & 57.8 & 1.7 & 3.7 \\
\hline Financial Intermediation & 40.9 & 51.6 & 0.5 & 1.5 \\
\hline Real Estate & 42.9 & 42.3 & 0.2 & 1.0 \\
\hline Leasing and Business Services & 55.6 & 45.4 & 0.1 & 0.6 \\
\hline Scientific Research, Technical Services, and Geological Prospecting & 30.3 & 32.4 & 0.1 & 0.4 \\
\hline Management of Water Conservancy, Environment and Public Facilities & 55.1 & 30.3 & 0.5 & 0.5 \\
\hline Services to Households and Other Services & 50.6 & 52.9 & 1.5 & 3.1 \\
\hline Education & 52.2 & 53.4 & 2.5 & 3.6 \\
\hline Health, Social Securities and Social Welfare & 56.0 & 58.5 & 1.4 & 2.6 \\
\hline Culture, Sports and Entertainment & 43.6 & 46.6 & 0.3 & 0.7 \\
\hline Public Management and Social Organization & 37.0 & 44.5 & 2.6 & 8.6 \\
\hline Others & -- & -- & 0.5 & -- \\
\hline Total & 47.7 & 44.7 & 100.0 & 100.0 \\
\hline
\end{tabular}

Source: The Second and Third Survey of Chinese Women's Social Status which were jointly organized by the All-China Women's Federation and the National Bureau of Statistics respectively in 2000 and 2010. 
Sex structure by Industry has undergone complicated changes compared with 10 years ago. First, male proportions in some traditional industries have increased. In the four traditional industrial categories (such as construction, transportation, storage and postal services, manufacturing, research and technical services and geological prospecting), the trend of male dominance is more evident. Secondly, in some industries, gender parity and gender segregation coexist; on the one hand, in the process of traditional population flow and industrial structure adjustment, men have more opportunities to be engaged in non-agricultural labors, while women are more likely to be left working in the low-income farming, forestry, animal husbandry, fishery and water conservancy industries; the proportion of females in the above mentioned industries further increased in 2010, and the gender gap was 2.3 percent higher than 10 years ago; on the other hand, with the continuous improvement of women's education levels, in some modern industries and public sectors (such as real estate, production and distribution of electricity, gas and water, public management and social organization) with higher requirements for human capital and higher income levels, the proportion of females has increased to some extent (see Table 2), which is significant for improving the quality of women's employment and promoting them to be more extensively involved in social production.

Farming, forestry, animal husbandry, fishery and water conservancy is the major industries that provide employment for women, while manufacturing and wholesales \& retails are respectively the second and the third largest industries for employed women. In 2010, more than 60 percent of the employed population in these three sectors was females, 28.1 percentpoints higher than males (see Table 2). The gap between female and male in these industries fully reflects the aggregation of females' employment fields, but also the low-quality feature of female employment.

Compared with 2000, the following changes have taken place in female industrial structure: Firstly, the proportion of employed females in farming, forestry, animal husbandry, fishery and water conservancy dropped significantly, providing adequate human resources for the second and the tertiary industries, which has created the conditions; for upgrading the female industrial structure. Secondly, the proportion of females in wholesiales and retails has the fastest growth rate in all industries. Finally, the proportion of females in public administration and social organizations shows a growth rate second only to that in wholesales and retails. If in the wholesales and retails the income and social security for employed women are low, the increase of the proportion of females in the public administration and social organizations can not only allow them to obtain higher income and social security, but also improve their employment and economic statuses.

4.2 Gender Segregation in Industries with High Degrees of Monopoly of China in the New Century

Table 3 shows the gender segregation in over a dozen of industries with high degrees of monopoly. Except the banking, postal and telecommunications sectors that see relative gender parity, in the other eight monopoly industries, females occupy not more than half of the total employed population, especially in rail transport and industries engaged in the 
production and supply of electricity, steam and hot water, the proportions of females are lower than 30 percent, indicating that in most of the monopoly industries, males have reaped the major parts of the profits.

Table 3. Gender segregation in industries with high degrees of monopoly of urban area in the year of 2000 and 2010 (\%)

\begin{tabular}{|c|c|c|c|c|c|c|}
\hline & \multirow{2}{*}{\multicolumn{2}{|c|}{$\begin{array}{l}\text { Women accounting for the } \\
\text { proportion of staff in the } \\
\text { industry }\end{array}$}} & \multicolumn{4}{|c|}{$\begin{array}{l}\text { Accounting for the proportion of } \\
\text { male/female staff in the industry }\end{array}$} \\
\hline & & & \multicolumn{2}{|c|}{ male } & \multicolumn{2}{|c|}{ female } \\
\hline & 2000 & 2010 & 2000 & 2010 & 2000 & 2010 \\
\hline Bank & 49.1 & 49.7 & 1.4 & 1.1 & 1.8 & 1.5 \\
\hline Real Estate & 36.8 & 36.8 & 0.5 & 2.2 & 0.4 & 1.8 \\
\hline $\begin{array}{l}\text { Postal and Telecommunications } \\
\text { Industry }\end{array}$ & 46.1 & 41.8 & 0.8 & 1.3 & 0.9 & 1.3 \\
\hline Manufacture of Tobacco & 43.3 & 38.1 & 0.2 & 0.1 & 0.2 & 0.1 \\
\hline Production and Distribution of Water & 40.4 & 35.8 & 0.3 & 0.3 & 0.3 & 0.2 \\
\hline $\begin{array}{l}\text { Production and Distribution of } \\
\text { Electricity, Gas and Water }\end{array}$ & 31.2 & 29.7 & 1.5 & 1.4 & 0.9 & 0.8 \\
\hline Production and Distribution of Gas & 34.7 & 32.9 & 0.2 & 0.2 & 0.1 & 0.1 \\
\hline $\begin{array}{l}\text { Extraction of Petroleum and Natural } \\
\text { Gas }\end{array}$ & 33.5 & 30.8 & 0.4 & 0.3 & 0.2 & 0.2 \\
\hline Air Transport & 38.0 & 39.3 & 0.1 & 0.2 & 0.1 & 0.2 \\
\hline Transport Via Railway & 27.1 & 24.3 & 1.5 & 1.1 & 0.7 & 0.5 \\
\hline Total & 38.2 & 37.2 & 6.9 & 8.3 & 5.6 & 6.7 \\
\hline
\end{tabular}

Source: The Second and Third Survey on Chinese Women's Social Status, which were jointly organized by the All-China Women's Federation and the National Bureau of Statistics respectively in 2000 and 2010.

The proportion of employed females in monopoly industries has been lower than that of males. Although over the past decade, the employment proportions of both males and females in industries with higher degrees of monopoly have increased to some degrees, the increase rate of females is still lower than that of males, thus widening the gender gap. Moreover, even in 2010, the proportion of employed women in industries with higher degrees of monopoly was still lower than the corresponding ratio of males a decade ago (see Table 3).

The lower proportion of females in industries with higher degrees of monopoly, their lower increase rate than males, and the decline of female proportion in industries with higher degrees of monopoly are the direct proofs of intensified gender discrimination and gender differentiation in monopoly industries, which is extremely unfavorable for women to equally share the outcomes of the development of monopoly industries.

\subsection{Gender Parity in the Modern Service Industry of China in the New Century}

In 2003, the $16^{\text {th }}$ National Congress of the Communist Party of China proposed to speed up the development of the modern service industry (note 1) and increase the weight of the tertiary industry in the national economy in the report titled "Building a moderately prosperous society and creating a new situation in the socialist cause with Chinese characteristics”, which plays a guiding role in adjusting industrial structure and promoting economic development. With the support of the state, the average salary of employees in the 
modern service industry in 2010 was 31.4 percent higher than employees at urban and township units. As an emerging industry, whether the modern service industry can provide women with equal employment opportunities, and whether women can obtain the corresponding higher incomes?

The modern service industry has created employment conditions for women. In the seven modern service sectors listed in Table 4, the proportions of females are not only higher than those in industries with high degrees of monopoly, but also very close to the proportion of employment females, which indicates the relatively balanced gender structure in the modern service industry. Compared with 10 years ago, the proportion of women in the modern service industry has increased by nearly 3 percentpoints, which shows that the modern service industry has created fair employment conditions for women and attracted a growing number of women to work in the modern service industry, resulting in the ever increasing degree of gender equality.

Table 4. Sex structure of modern service industry in the year of 2000 and 2010 (\%)

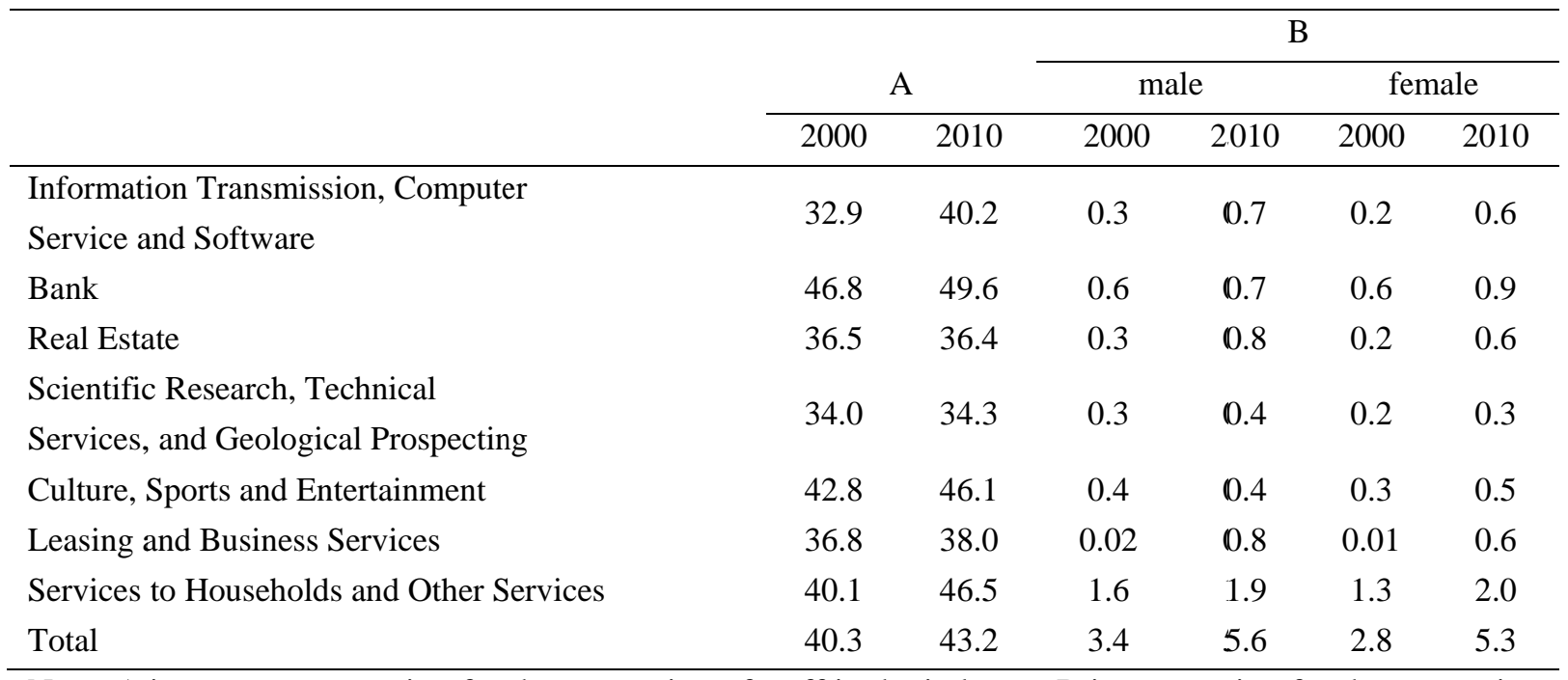

Note: A is women accounting for the proportion of staff in the industry; B is accounting for the proportion of male/female staff in the industry.

Source: The Second and Third Survey of Chinese Women's Social Status which were jointly organized by the All-China Women's Federation and the National Bureau of Statistics respectively in 2000 and 2010.

The proportion of employed women in the modern service industry out of the total number of employees is in continuous increase. Of all the employed females in 2010, 5.3 percent worked in the modern service industry, which almost doubled the figure in 2000. Compared with males, the increase rate of females was greater, thus promoting the level of gender parity in the modern service industry, where more and more women can obtain higher incomes.

The result of the logistic regression analysis. A forced entry strategy is used to estimate the model with the SPSS software. The comprehensive test on the model coefficients shows a significant regression equation. The value of -2 Log likelihood is 11996.85 , which shows that 
this model has a good fit. The value of Nagelkerke $\mathrm{R}^{2}$ is 0.133 .

Table 5 shows the result of the logistic regression analysis. Most of the independent variables are significant at the level of $\mathrm{p}<0.05$. There is no statistical significant difference between male and female, that is to say, compared with male, there is no employment discrimination in modern service industry. While younger and higher level of education, working in urban area, place of birth is county and city, and experienced career break have significantly statistical effects on the opportunities of modern service industries' employment.

Table 5. Variables in the equation

\begin{tabular}{|c|c|c|}
\hline & $\mathbf{B}$ & $\operatorname{Exp}(B)$ \\
\hline Sex $($ male $=0)$ & -0.034 & 0.967 \\
\hline \multicolumn{3}{|l|}{ Age group (60-64 years old=0 ) } \\
\hline 18-29 years old & $0.384^{* *}$ & 1.469 \\
\hline 30-39 years old & 0.127 & 1.136 \\
\hline 40-49 years old & 0.082 & 1.085 \\
\hline 50-59 years old & -0.045 & 0.956 \\
\hline \multicolumn{3}{|l|}{ Education(Secondary and below $=0$ ) } \\
\hline High school & $0.372^{* * *}$ & 1.451 \\
\hline College and above & $0.805^{* * *}$ & 2.237 \\
\hline \multicolumn{3}{|l|}{ Area (west area $=0$ ) } \\
\hline Beijing, Tianjin, Shanghai & $0.334^{* * *}$ & 1.396 \\
\hline East area & $-0.205^{* *}$ & 0.815 \\
\hline Middle area & -0.13 & 0.878 \\
\hline Rural and Urban (Rural area $=0$ ) & $1.371^{* * *}$ & 3.941 \\
\hline \multicolumn{3}{|l|}{ Place of birth(Rural area=0) } \\
\hline Town & 0.04 & 1.041 \\
\hline County (including county-level cities) & $0.343^{* * *}$ & 1.409 \\
\hline City (prefecture-level cities and above) & $0.337^{* * *}$ & 1.401 \\
\hline The way of getting work (non-organization =0) & $-0.656^{* * *}$ & 0.519 \\
\hline Career break $(\mathrm{no}=0)$ & $0.394^{* * *}$ & 1.483 \\
\hline Communist Party membership $(\mathrm{no}=0)$ & -0.138 & 0.871 \\
\hline Ability of women is poor than that of men (do not agree $=0$ ) & -0.018 & 0.982 \\
\hline Constant & $-3.714^{* * *}$ & 0.024 \\
\hline 2 Log-likelihood values & \multicolumn{2}{|c|}{11996.85} \\
\hline Nagelkerke R Square & \multicolumn{2}{|c|}{0.133} \\
\hline $\mathbf{N}$ & \multicolumn{2}{|c|}{24717} \\
\hline
\end{tabular}

\section{Conclusions and Discussions}

If viewed from the perspective of gender structures in different industries, females are mostly concentrated in sectors with lower levels of income and social security, where gender segregation and gender parity coexist. Compared with 10 years ago, the proportion of employed females in farming, forestry, animal husbandry, fishery and water conservancy industry shows a substantial decline, while the increase rates of the proportions in wholesales 
and retails, and in public administration and social organizations are the first two highest. The proportion of females in industries with higher degrees of monopoly is low, and the declining tendency reflects the intensified gender discrimination and gender differentiation in monopoly industries; the proportion of females in the modern service industry as well as the degree of gender parity in the industry have been increasing, making it possible for more and more women to obtain higher incomes. The result of binary logistic regression shows that age and education, have significantly statistical effects on the opportunities of modern service industries' employment.

The industry-related gender segregation reflects the actual inequality in employment, which is restricted by both the level of economic development and the industrial structure and the mode of development. Moreover, it is also related to the differences in men and women. In order to comprehensively improve the quality of women's employment, and effectively promote the coordinated development of the industrial gender structure, this article makes the following suggestions:

It is necessary to introduce a national level "gender equality promotion regulations" as soon as possible, to clearly stipulate from the perspective of law that gender equality is the equality of the dignity and worth of both genders as well as the formal and substantive equality in terms of opportunities, rights and responsibilities on basis of respecting their physiological differences. Meanwhile, it is also important to establish working bodies engaged in promoting gender equality, and develop gender analysis and evaluation mechanisms for public policies, to ensure the sustainability of promoting gender equality; it is necessary to strengthen the efforts in punishing gender discrimination in employment on the labor market, to effectively reduce occupational and industrial gender segregation, and promote women's development. In addition, the employers, especially those who offer higher average incomes, should initiatively provide women with equal employment and development opportunities in the process of recruitment, appointment and promotion.

\section{Acknowledgement}

This article data come from the Third Survey of Chinese Women's Social Status, which was jointly organized by the All-China Women's Federation and the National Bureau of Statistics starting on December 1, 2010. I would like to show my deepest gratitude to the All-China Women's Federation and the National Bureau of Statistics. And I also would like to show my deepest gratitude to Women's Studies Institute of China funding me to participate in the XVIII World Congress of Sociology to present this paper.

\section{References}

Blau, F. D., \& Hendricks, W. E. (1979). Occupational segregation by sex: Trends and prospects. Journal of Human Resources, 14(2), 197-210. http://dx.doi.org/10.2307/145642

Del Rio, C., \& Alonso-Villar, O. (2010). Gender segregation in the Spanish labor market: An alternative approach. Social Indicator Research, 98(2), 337-362. http://dx.doi.org/10.1007/s11205-009-9548-0

Falk, S. (2002). Geschlechtsspezifische und berufliche Segregation in Ostdeutschland 
zwischen Persistenz, Verdrangung und Angleichung: ein Vergleich mit Westdeutschland für die Jahre 1991-2000. Mitteilungen aus der Arbeitsmarkt- und Berufsforschung, 35(1), 37-59.

Stephan, H. (2013). Age and Gender Differences in Job Opportunities. International Journal of Human Resource Studies, 3(1), 104-133. http://dx.doi.org/10.5296/ijhrs.v3i1.3067

Irene, K., Marlis, B., \& Stefan, S. (2010). Variation in job opportunities for men and women in the Swiss labor market 1962-1989. Research in Social Stratification and Mobility, 28, 309-323. http://dx.doi.org/10.1016/j.rssm.2010.03.002

J. Blazejczak. (1991). Evaluation of the long-term effects of technological trends on the structure of employment. FUTURES. July/August 594-604. http://dx.doi.org/10.1016/0016-3287(91)90081-C

Jiang, Y. (2006). Socio-economic status of women. in Women's Studies Institute of China, Chinese women's social status in social transformation (pp. 161). Beijing: China Women Publishing House (In Chinese).

Luo, Y. (2008). A Study of discrimination in China's urban labor market. Unpublished doctoral dissertation, Jilin University, Changchun, China.

Rendall, M. (2010). Brain versus brawn: The realization of women's comparative advantage. IEW-Working Papers 491, Institute for Empirical Research in Economics-IEW.

Tan, L., \& Bu, W. (1995). Occupational and industrial gender segregation in the Chinese population and the causes. Collection of Women 's Studies, (1), 24-28 (In Chinese).

Xu, D., \& Yang, Z. (2012). Study on the measurement and trends of gender segregation in the industrial structure. Human Resources Development of China, (2), 16-23 (In Chinese).

$\mathrm{Xu}, \mathrm{Y}$. (2008). Female Employment Status from the Gender Perspective-the Experience of Company C, Unpublished Master dissertation, Nangchang University, Nanchang, China.

Zhang, K. (2010). Gender discrimination and social exclusion in the labor market. Sciences Press (In Chinese).

\section{Note}

1. The typical sectors in the modern service industry are finance and insurance, information transmission and computer software, leasing and business services, scientific and technical services and geological prospecting, culture, sports and entertainment, real estate and residential community services. http://baike.baidu.com, access date: August 29, 2013. 
Appendix

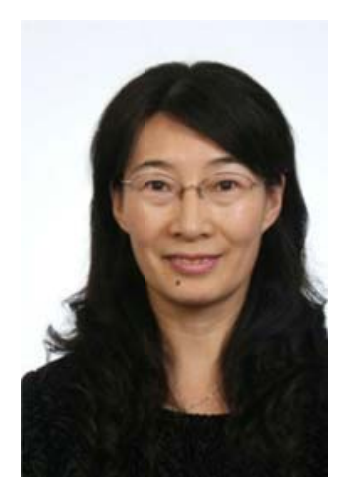

Hui YANG is a Doctor and Associate Research Fellow of Women's Studies Institute of China (WSIC), All-China Women's Federation. She graduated from the Renmin University of China in 2009 and received a Ph.D. in Gerontology. Her previous research interests are aging and women development, current interested research fields are gender issues and women development. She is a member of International Union for the Scientific Study of Population (IUSSP) and the International Association for Feminist Economics (IAFFE). Ten papers in English and sixty papers in Chinese have been published.

\section{Copyright Disclaimer}

Copyright for this article is retained by the author(s), with first publication rights granted to the journal.

This is an open-access article distributed under the terms and conditions of the Creative Commons Attribution license (http://creativecommons.org/licenses/by/3.0/). 